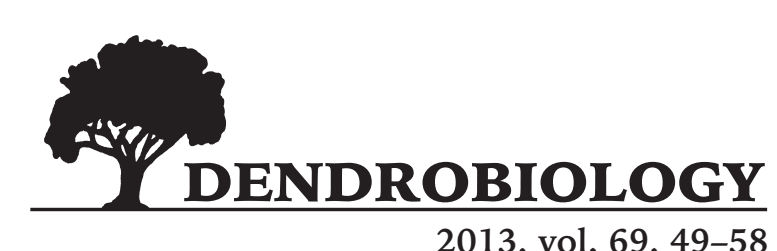

2013, vol. $69,49-58$

\author{
Barbora Kučeravá, Lumír Dobrovolný, Jiř́ Remeš
}

\title{
Responses of Abies alba seedlings to different site conditions in Picea abies plantations
}

Received: 25 May 2012; Accepted 4 September 2012

\begin{abstract}
Introduction of silver fir (Abies alba Mill.) as one of the historically important coniferous tree species in Central Europe into allochthonous cultivated forests is an important task for contemporary and future generations of foresters. The aim of our work was to optimize the management of fir in allochthonous cultivated stands of National Park České Švýcarsko formed mainly by Norway spruce (Picea abies /L./Karst.). The effects of light and soil conditions and game on the survival and growth of fir plantations were investigated. Browsing was determined as the limiting factor for fir reintroduction. Assessing the significance of edaphic conditions for the height increment of fir, favourable effect of luvisol could be demonstrated as compared to acidic soil. Canopy openness maximum of $30 \%$ and stand basal area of 30 to $43 \mathrm{~m}^{2} /$ ha with relative direct radiation of up to $45 \%$ and relative indirect radiation of up to $55 \%$ with prevalence of the diffuse component create optimal environmental conditions for the survival and sustainable growth of fir plantations in the spruce stand in regeneration.
\end{abstract}

Additional key words: silver fir, Norway spruce monoculture, artificial regeneration, browsing, National park České Švýcarsko

Addresses: B. Kučeravá, J. Remeš, Czech University of Live Sciences Prague, Faculty of Forestry and Wood Sciences, Kamýcká 117616521 Praha 6 - Suchdol, Czech Republic, e-mail: kucerava@fld.czu.cz

L. Dobrovolný, Mendel University in Brno, Faculty of Forestry and Wood Technology Zemědělská 3, 61300 Brno, Czech Republic

\section{Introduction}

Generally, a decline of silver fir has been going on in Europe for the last two centuries (Musil 2003; Šindelář and Frýdl 2004; Kuneš et al. 2005; Abraham 2006; Zerbe 2002; Diaci 2002; Mosandl and Kleinert 1998; Kuiters and Slim 2002; Pèlachs et al. 2009). In typical fir regions of the Balkan Peninsula, this trend has been mostly attributed to the effects of past air pollution and, more recently, to the increasing negative impact of game (e.g. Diaci et al. 2010). Also in Southern Germany, air pollution (specifically $\mathrm{SO}_{2}$ pollution) played a key role in the decline and dieback of fir (Elling et al. 2009). In the Czech Republic, fir de- cline has received long-term attention and has been attributed mainly to changes in soil chemistry, insect pests, fungal diseases and, in particular, to the introduction of the clear-cutting system (Budín 1947; Svoboda 1953; Málek 1983; Musil 2003; Šindelář and Frýdl 2004; Úradníček and Maděra 2005). The share of fir in Czech forests has decreased, over past few centuries, from $20 \%$ to only $1 \%$. This totally inadequate representation has to be increased to at least $4.5 \%$. This value is recommended by the Ministry of Agriculture of the Czech Republic as an optimized compromise between natural species composition of the forest before human influence and the optimal species composition from an economic aspect. Fir 
was mostly replaced by spruce, which was more demanded by the industry and is easier cultivated. The share of spruce has thus increased from the original $11 \%$ to the current $51.9 \%$. This dramatic increase in the proportion of spruce, however, brought massive expansion of even-monocultures with negative effects on the stability and biodiversity of forests (Kazda and Pichler 1998; Diaci 2002). Increased stability and preservation of forest soil fertility is the main reason why the proportion of spruce should be reduced to about $36 \%$. This plan is being implemented by planting of suitable stability and amelioration trees such as fir, beech and oak (Mze 2010). In National Park České Švýcarsko (NPČŠ), fir receded from $20 \%$ of the area to $0.1 \%$ only (Lesprojekt 2007 ).

Due to the sporadic presence of fir in NPČS and the whole Czech Republic, natural regeneration can be utilized only to a limited extent. Artificial regeneration has to be therefore adopted to reintroduce fir to areas where it is currently absent and desirable (Šindelář and Frýdl 2004) accepting, at the same time, its ecological requirements. One of the most important characteristics of this species is its ability to withstand long-term shading (Kantor 2001; Stancioiu and O'Hara 2006a; Stancioiu and O'Hara 2006b; Stancioiu and O'Hara 2006c). This tolerance, however, varies with habitat conditions - shading is better tolerated in more favourable conditions (Kantor 2001). Fir prefers oceanic climate with mild winters, fresh and moist soils with higher nutrient content. It prospers better in high humidity and low air flow. Young trees are highly sensitive to late frosts and sudden sun exposure (Svoboda 1953; Musil 2003). Thus, precipitation and related droughts as well as high temperatures are the limiting factors at altitudes below 600 m.a.s.l. (Pinto et al. 2008) while growth is limited by low temperatures and late frost in high altitudes (Úradníček 2009; Maxime and Hendrik 2011). Additionally, excessively waterlogged and marshy habitats are avoided.

Dai (1996) and Nicotra et al. (1999) highlight light conditions as the key factor in stand management. Their change may significantly affect the microhabitat conditions such as soil moisture, air flow or temperature and thus the species composition of the forest. It is therefore desirable, according to many authors (Grassi and Bagnaresi 2001; Kantor 2001; Musil 2003; Stancioiu and O'Hara 2006b, Muscolo et al. 2010), to restore fir gradually by less intense cutting to avoid the exposure of the young trees to extreme microclimate changes. This implies that fir is not a suitable tree species for the clear-cutting system (Budín 1947; Svoboda 1953; Kantor 2001). In a large gap, the adaptability of fir natural regeneration is limited and it may be suppressed by more adaptable tree species such as the spruce (Stancioiu and O'Hara 2006c). Muscolo et al. 2010, determined the opti- mum gap size to $185 \mathrm{~m}^{2}$ to meet the ecological requirements of silver fir natural regeneration (Phillips and Shure 1990; Muscolo et al. 2007). It is also recommended to regenerate fir under a shelterwood (Grassi and Bagnaresi 2001; Kantor 2001; Musil 2003).

When fir is regenerated in spruce stands it should be ensured that natural regeneration of spruce is absent as it may negatively affect the development of fir (Zatloukal 2001). The growth of fir is initially very slow in comparison with spruce unless grown in shadow (Musil 2003). High adaptability of spruce to environmental conditions even increases with increasing height increment (Stancioiu and O'Hara 2006a). For these reasons, fir has to be regenerated in advance. Zatloukal (2001) recommended to start spruce regeneration when fir has a minimum height of $1 \mathrm{~m}$.

It has been confirmed that fir competes more successfully with spruce in shady conditions (Hunziker and Brang 2005; Stancioiu and O'Hara 2006b; Stancioiu and O'Hara 2006c). When the stand basal area exceeds $30 \mathrm{~m}^{2} / \mathrm{ha}$ and the percentage of above canopy light (PACL) declines below 25-30\%, spruce can be completely eliminated (Stancioiu and O'Hara 2006b). The fastest lateral and terminal growth of fir seedlings has been described in conditions of $18 \%$ radiation intensity (Robakowski et al. 2003), but exact values might vary with site conditions.

A major limiting factor for fir regeneration in spruce forests is browsing, which requires long-term protection (Zatloukal 2001). Younger seedlings often die after browsing. Fir regeneration with a damaged terminal requires at least two years replacing the lost height (Hasler et al. 2008).

Knowledge of the interactions between microclimatic conditions and stands in conjunction with information now available on tree ecophysiology enable to design viable applications useful for silviculture during stand formation and for the application of silvicultural treatments (Aussenac 2000). The aim of this study was therefore to analyze the growth of fir seedlings in relation to different light and soil conditions in spruce monocultures as well as the effect of game, and thus to collect the necessary information for an effective management of fir in the NPČŠ area.

\section{Materials and methods}

\section{Permanent research plot and site conditions}

National Park České Švýcarsko $\left(79.32 \mathrm{~km}^{2}\right)$ is situated in the northern part of the Czech Republic $\left(50.883542^{\circ} \mathrm{N} 14.389344^{\circ} \mathrm{E}\right)$. Its altitude ranges between 120 and 619 m.a.s.l. (Härtel et al. 2007), the average precipitation is $600-800 \mathrm{~mm}$ per year and av- 
erage temperature $7-8^{\circ} \mathrm{C}$. Soils are mostly acidic, formed on sandstone, with prevailing soil type Cambisol. Most of the park is located in intermediate altitude in the beech and fir - beech forest altitudinal zone and covered to a large extent with artificial spruce stands (Lesprojekt 2007). Potential species composition corresponds to the type Fageta quercino abietina and Piceosa Fageta abietina (Plíva 1987).

Ten permanent research plots (PRP) ranging in size from 800 to $1600 \mathrm{~m}^{2}$ were established in existing fir plantations in spruce monocultures in the regeneration stage. The plots were delimited to contain at least 40 seedlings suitable for evaluation. The fir planting took place between 2007 and 2009 (every year in spring) by dibble planting and irregular spacing using container-grown plants. The seedling numbers had to be at least 1500 plants per hectare. The plots were located on the predominant site type with intermediate altitude and acidic soils, namely acid soil - six research plots on forest types $4 \mathrm{~K}$ (Fagetum acidophilum), 5K (Abieto-Fagetum acidophilum), and four research plots on ilimeritic soils (luvisol) - forest types 4I (Fagetum illimerosum acidophilum), 5I (Abieto-Fagetum illimerosum acidophilum). Plots are situated in the beech and fir - beech forest altitudinal zone, where the potential species composition of the stands is Fageta quercino abietina and Piceosa Fageta abietina (Pliva 1987). Elevation of the plots fluctuated between $380-450 \mathrm{~m}$. The plots were situated in plain terrain or on gentle northern (plot 1 and 4) and western exposure slopes (plot 13) of up to $10 \%$.

\section{Data collection}

The state of the plots was mapped by the Field Map technology in 2010 and 2011. Specifically, the following parameters were determined: the position of the trees of the upper storey and regeneration, mensurational data of the trees of the upper storey (tree height and crown length, diameter at breast height and crown projection area - see Fig. 1). Annual height increments were measured in the fir seedlings starting one year after afforestation (from 2008 to 2011) to exclude planting shock. The diameter its increment was determined for 2011. The seedling health stage was scored in all seedlings by ocular evaluation of the yellowing, foliage and browsing at the same time. Plot 1 was the only unfenced plot and was therefore used for the evaluation of the effect of game.

Canon EOS 1100D with lens Sigma 4.5 mm/F2.8 EX DC Circular Fisheye HSM Canon was used to determine the light conditions by the Fish-eye approach (Canham et al. 1990; Nicotra et al. 1999; Dobrovolný 2010). 1460 photos were created under 3 different apertures in a gridline of $5 \times 5 \mathrm{~m}$. One photo with optimal luminance was selected for each point (487 in total), which was then transformed via the blue color spectrum to black and white in the program Sidelook.

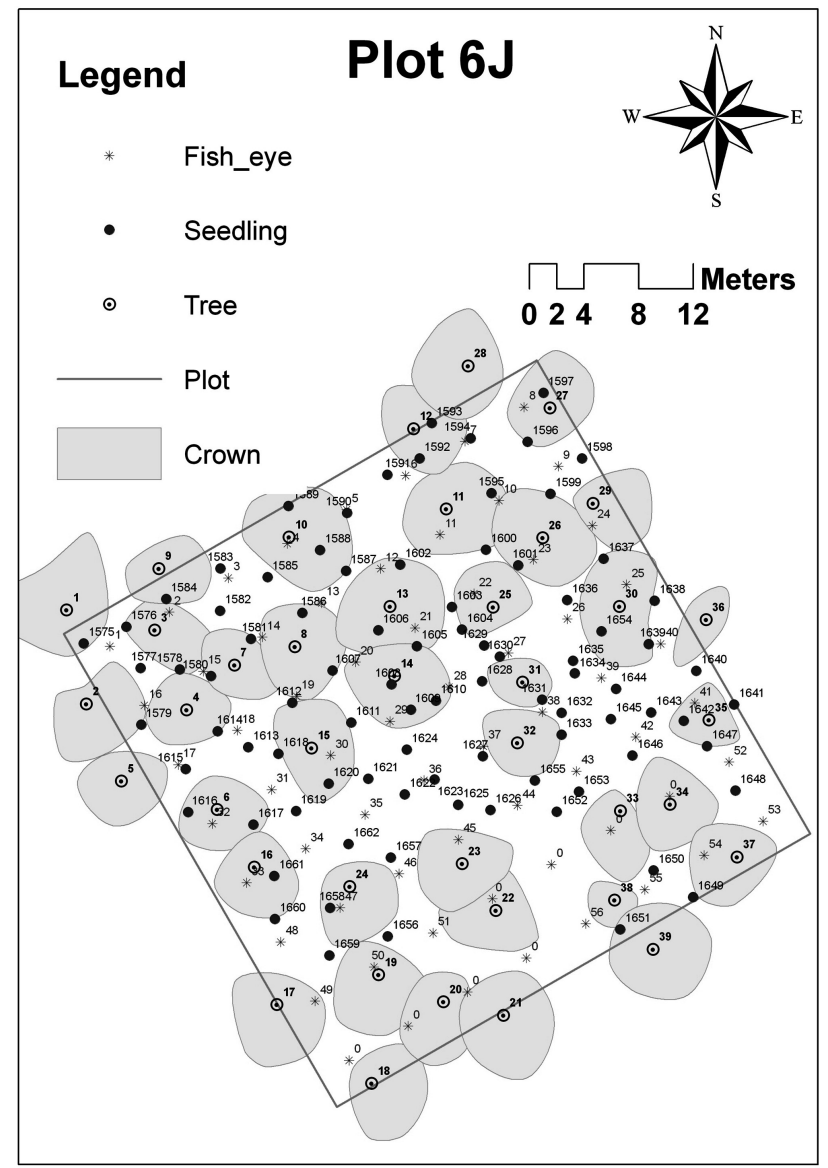

Fig. 1. Map of plot 6

Subsequently, the hemispherical photos were analyzed by the program WinScanopy Reg 2008 with the following outputs: gap fraction, openness, direct site factor (DSF), indirect site factor (ISF) and total site factor (see Table 1). Buffer with $2.5 \mathrm{~m}$ radius was created around each point on the $5 \times 5 \mathrm{~m}$ grid using the programme Arc Gis 9.3 and information from the analysis of the hemispherical photographs of the central point. This information was then assigned to each fir seedling located in the buffer area.

\section{Data analyses}

Seedlings were planted between 2007 and 2009, therefore tested the effect of different time of afforestation for height increment and increment of diameter at root collar by Spearman correlation coefficient.

The increments of the fir seedlings were compared among each other and with the light and site conditions. First, the basic growth characteristics of the plantations on the individual research plots (median, standard deviation) were calculated as well as average values of the parameters characterizing the light regime on the research plots (DSF, ISF, DSF: ISF, openness).

A comparison of the height and diameter increment of the fir plants was performed among the research plots (2010 and 2011) using Wilcoxon 


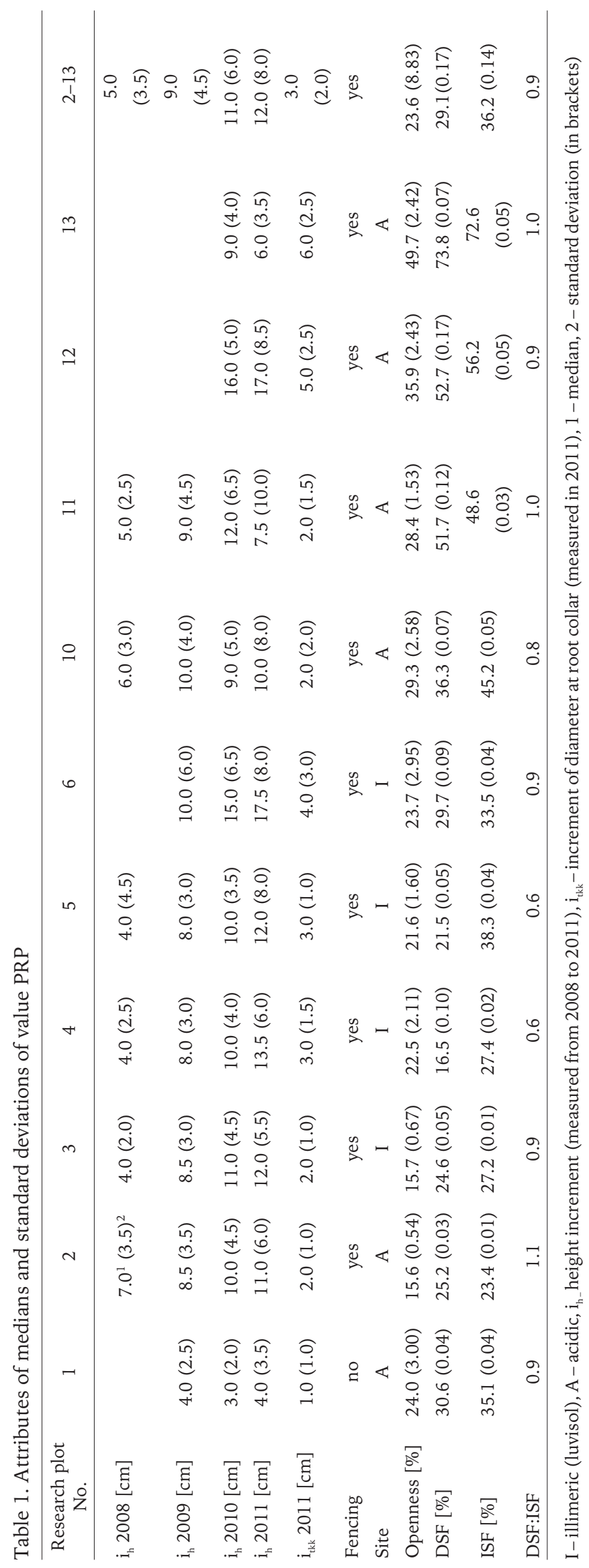


non-parametric test. Furthermore, dependency of the growth of seedlings on lighting conditions (factors: DSF, IFS, DSF:ISF, openness) was assessed by Spearman correlation coefficient in the statistical softwares $\mathrm{R}$ ( $\mathrm{R}$ for Windows GUI (R 2.14.1)) and Statistics (Statsoft, version 9). Statistical significance level was set as probability level $\mathrm{P}=0.05$ for all data. Figures 2-7 show the medians with upper and lower quartiles.

\section{Results}

\section{Basic growth characteristics}

The annual height increment of fir reached the following median values (minimum - maximum) in the period 2008-2011 (Table 1): $5 \mathrm{~cm}$ (1-32), $9 \mathrm{~cm}$ (0-25), $11 \mathrm{~cm}(1-30)$ and $12 \mathrm{~cm}(1-43)$. The height increment of fir thus increased slightly in the years following planting on most plots except plot 1 and 13, where the trend was rather opposite (see Table 1). The differences in height increment depended on the plot. Plot 1 differed from the others most pronouncedly as it was unfenced and thus exposed to game browsing, which affected $39 \%$ of the seedlings by browsing the terminal shoot. The evaluation of all the plots was possible only in 2010 and 2011 due to the differences in planting time. In this time period, plots 6 and 12 can be distinguished with the highest increment and plot 13 with the lowest increment. The mean diameter increment in 2011 was $3 \mathrm{~mm}$ (0-17 $\mathrm{mm}$ ) and the differences among plots were similar as for the height increment. The impact of different time of afforestation (2007-2009) for height increment ( $R$ $=-0.06054, \mathrm{p}=0.05)$ and increment of diameter at root collar $(\mathrm{R}=-0.27435, \mathrm{p}=0.05)$ was not significant, probably due relatively short interval between planting.

\section{Edaphic conditions}

The size and dynamics of the height increment of fir depended on habitat type. Specifically, statistically significant differences between the soil types were found in the years $2008(\mathrm{U}=11580.5, \mathrm{p}=0.000)$ and 2011 ( $U=20619.5$, $\mathrm{p}=0.000)$ in the Mann - Whitney U Test. The increment was significantly higher on the acidic soil than on the luvisol in 2008. In the subsequent years, however, the increment equalized on both soil types, and finally, became greater on the luvisol in 2011. Figure 2 shows that the dynamics of height increment was generally more balanced and continuously growing on the luvisol. The diameter increment was not affected by soil type.

\section{Light conditions}

Plot 1, where fir growth was limited by game, was excluded from the evaluation of the effects of light

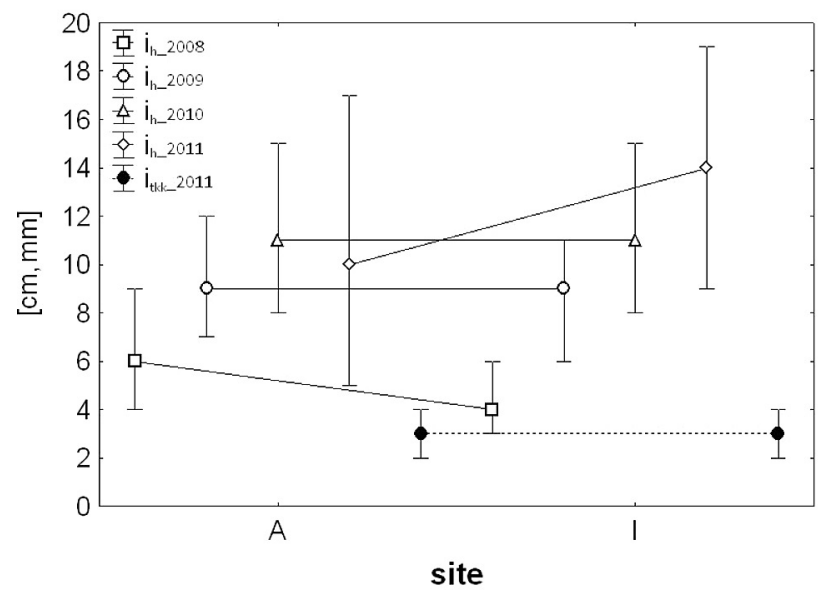

Fig. 2. Dynamics of height and diameter increment of fir depending on the soil type

A - acid, I - luvisol, $\mathrm{i}_{\mathrm{h}-}$ height increment (measured from 2008 to 2011), $i_{\text {tkk }}$ - increment of diameter at root collar (measured in 2011)

conditions. The parameter "openness", which median was $23.6 \%$ (range $14.2-52.3 \%$ ) significantly differed among the plots. The lowest values were recorded on plots 2 and 3, the highest values on plot 13. Similarly, the parameters DSF - 29.1\% (8.1 - 85.1\%) and ISF $36.2 \%$ (20.8 - 77.4\%) significantly differed among most plots. DSF values were the lowest on plot 4 and the highest on plot 13, while ISF was the lowest on plot 2 and the highest on plots 12 and 11 . The median of the DSF: ISF ratio was 0.9 (0.3 to 1.4$)$, i.e. in favour of the diffuse component. The proportion of the diffuse component was the largest on plot 4 and 5 , the smallest on plot 2 .

DSF and ISF had mostly no significant effect on the height and diameter increment of the seedlings on the individual plots. Correlations between the light parameters and the growth characteristics of the fir seedlings were in most cases weakly significant. The significant correlations are summarized in Table 2.

The height and diameter increment of fir was thus influenced by light conditions only to a certain extent. A categorical expression (categories created to comprise 5 per cent) of the factor enabled a better under-

Table 2. Spearman coefficients of research plots with significant correlations $(P<0.05)$ of fir increments

\begin{tabular}{lcccccccc}
\hline & \multicolumn{4}{c}{ DSF } & \multicolumn{5}{c}{ ISF } \\
\hline Plot & 3 & 4 & 5 & 10 & 4 & 6 & 10 & 11 \\
$\mathrm{i}_{\mathrm{h}} 2008$ & & -0.34 & & -0.26 & -0.32 & & -0.28 & \\
$\mathrm{i}_{\mathrm{h}} 2009$ & & -0.29 & & & -0.35 & & & \\
$\mathrm{i}_{\mathrm{h}} 2010$ & 0.33 & & -0.25 & -0.47 & & & & \\
$\mathrm{i}_{\mathrm{h}} 2011$ & 0.27 & & -0.48 & -0.29 & & 0.22 & & 0.39 \\
$\mathrm{i}_{\text {tkk }} 2011$ & & & -0.28 & & & 0.22 & & 0.39 \\
N of plants & 60 & 58 & 64 & 59 & 58 & 88 & 59 & 59 \\
\hline
\end{tabular}

DSF - direct site factor, ISF - indirect site factor, $\mathrm{i}_{\mathrm{h}}$ height increment (measured from 2008 to 2011), $i_{\text {tkk }}$ - increment of diameter at root collar (measured in 2011), $\mathrm{N}$ of plants - Sample size of plants 


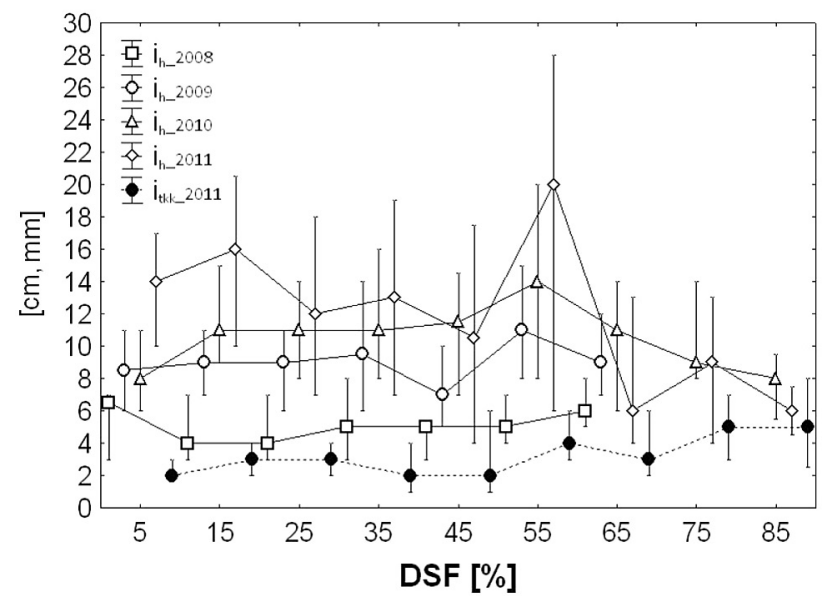

Fig. 3. Dependence of the height and diameter increment of fir seedlings on the amount of direct site light (DSF) $\mathrm{i}_{\mathrm{h}}$ - height increment (measured from 2008 to 2011), $\mathrm{i}_{\mathrm{tkk}}$ - increment of diameter at root collar (measured in 2011)

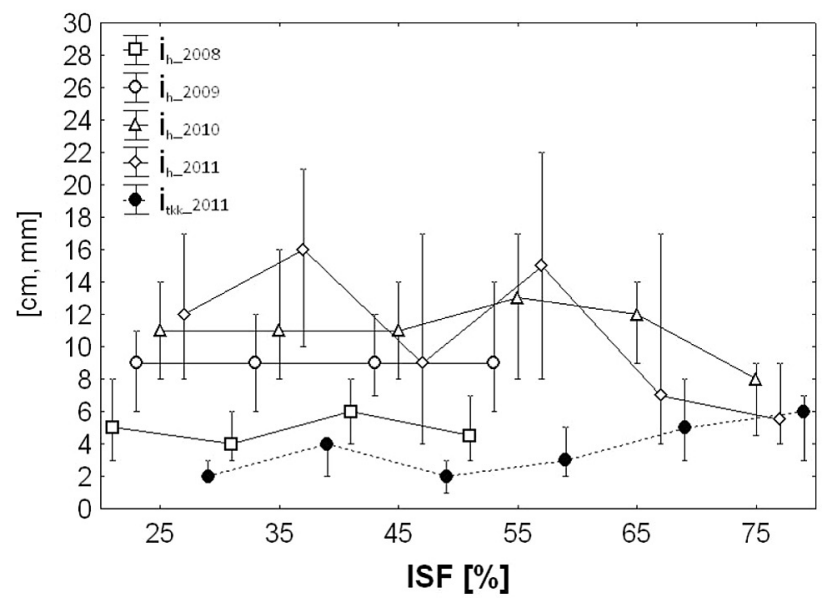

Fig. 4. Dependence of the height and diameter increment of

fir seedlings on the amount of indirect site light (ISF)

$\mathrm{i}_{\mathrm{h}}$ - height increment (measured from 2008 to 2011), $\mathrm{i}_{\text {tkk }}$ - increment of diameter at root collar (measured in 2011)

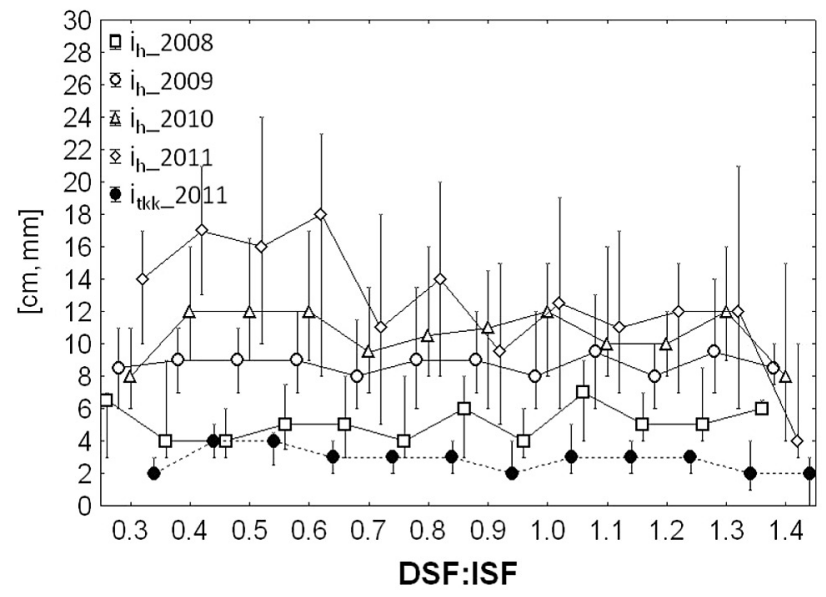

Fig. 5. Dependence of height and diameter increment of fir seedlings on ratio of DSF:ISF

$\mathrm{i}_{\mathrm{h}}$ - height increment (measured from 2008 to 2011), $\mathrm{i}_{\mathrm{tkk}}$ - increment of diameter at root collar (measured in 2011)

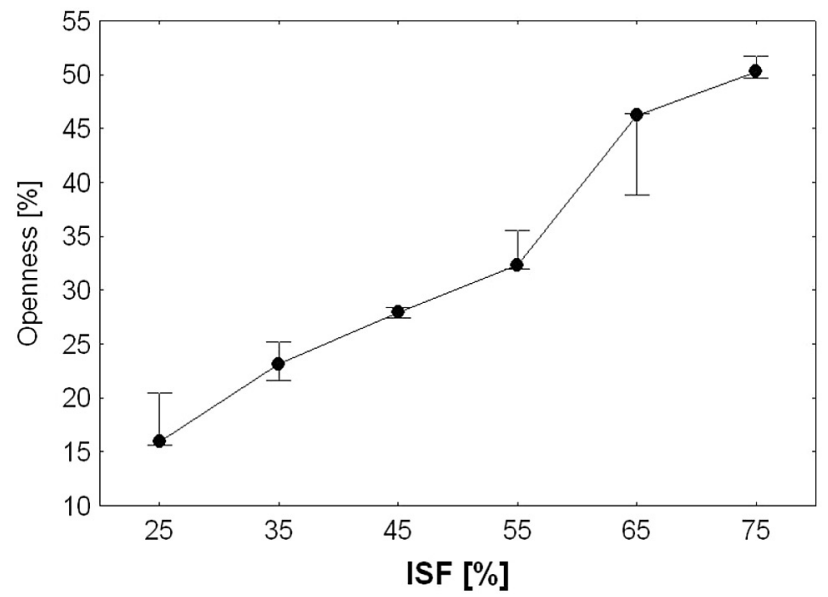

Fig. 7. Relationship between canopy openness and ISF

standing of the investigated relationship. It can be divided into the effects of the direct and the diffuse component and the effect of their ratio DSF: ISF (Fig. 3, 4 and 5).

For the direct component, differences in fir increment were found in the interval of categories DSF from $5 \%$ to $85 \%$. The height increments did not significantly differ in 2008 and 2009 (Fig. 3). In the subsequent years, however, substantial differences in height increments were observed, which were most pronounced in 2011 (see Fig. 3). These significant differences were mostly found between DSF categories $15-55 \%$ on one hand and categories $65-85 \%$ on the other hand. For the diameter increment, significant differences were confirmed between the values of the categories $5 \%$ and $25 \%$ on one hand and the categories $55 \%, 75 \%$ and $85 \%$ on the other hand (Table 3 ).

For the diffuse component of light radiation, differences in fir increment were found in the interval of categories ISF from $25 \%$ to $75 \%$ (Fig. 4). In contrast to DSF, height increments significantly differed between the ISF categories already in 2008 with significant differences between $35 \%$ and $45 \%$ ISF (Table 4 ). No significant differences were found for the year 2009. As evident from Figure 4, the differences in height incre-

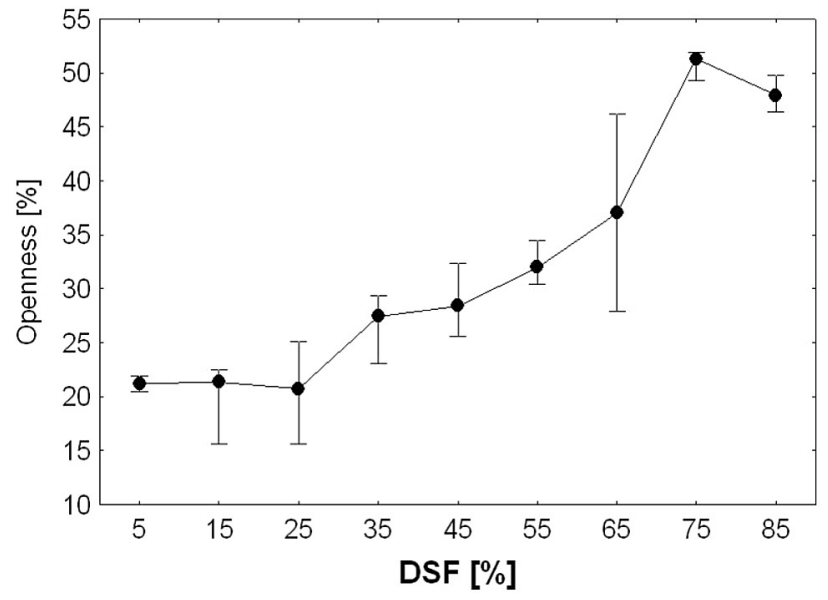

Fig. 6. Relationship between canopy openness and DSF 
Table 3. Significant differences in increments between DSF categories

\begin{tabular}{lcc}
\hline \multicolumn{1}{c}{ Increment } & Value of DSF (\%) & $\begin{array}{c}\text { Significantly different } \\
\text { from DSF (\%) }\end{array}$ \\
\hline $\mathrm{i}_{\mathrm{h} \_} 2010$ & 55 & 85 \\
$\mathrm{i}_{\mathrm{h} \_} 2011$ & 15 & $65,75,85$ \\
$\mathrm{i}_{\mathrm{h} \_} 2011$ & 25 & 65 \\
$\mathrm{i}_{\mathrm{h} \_} 2011$ & 35 & 65,85 \\
$\mathrm{i}_{\mathrm{h} \_} 2011$ & 55 & $65,75,85$ \\
$\mathrm{i}_{\mathrm{tkk}-2} 2011$ & 5 & $55,75,85$ \\
$\mathrm{i}_{\mathrm{tkk}-2011} 25$ & 75 \\
$\mathrm{i}_{\text {tkk_ }} 2011$ & 25 & 55,75 \\
\hline
\end{tabular}

DSF - direct site factor, $\mathrm{i}_{\mathrm{h}-}$ height increment (measured from 2008 to 2011), $i_{\mathrm{tkk}}$ - increment of diameter at root collar (measured in 2011)

ment were most pronounced in 2011, again, where significant differences were confirmed between the $25 \%$, $35 \%$ and $55 \%$ ISF categories on one hand and $75 \%$ on the other hand, as well as between $35 \%$ on one hand and $45 \%$ and $65 \%$ on the other hand. The most pronounced differences were observed in the diameter increment values, where the increment in $25 \%$ ISF was significantly different from the values in the ISF categories $35 \%, 55 \%, 65 \%$ and $75 \%$.

The effect of the ratio of the direct to the diffuse light component (DSF:ISF) was analyzed for categories in the interval from 0.3 to 1.4 (Fig. 5). Height increments did not principally differ between the categories in 2008, 2009 and 2010. Significant differences were determined only for the height increment in 2011 with the value in the 0.6 category of DSF:ISF significantly different from the values in the 0.9 and 1.4 categories. Again, the most pronounced differences were found in the diameter increment, which values significantly differed between the categories 0.3 and 0.4 as well as between 0.4 (with the highest values) on one hand and 0.7, 1.2 and 1.4 on the other hand.

Table 4. Significant differences in increments between ISF categories

\begin{tabular}{lcc}
\hline Increment & Value of ISF (\%) & $\begin{array}{c}\text { Significantly different } \\
\text { from of ISF (\%) }\end{array}$ \\
\hline $\mathrm{i}_{\mathrm{h} \_} 2008$ & 35 & 45 \\
$\mathrm{i}_{\mathrm{h} \_2} 2010$ & 35,55 & 75 \\
$\mathrm{i}_{\mathrm{h} \_2} 2011$ & $25,35,55$ & 65 \\
$\mathrm{i}_{\mathrm{h} \_} 2011$ & 35 & 45,65 \\
$\mathrm{i}_{\mathrm{tkk} \_} 2011$ & 25 & $35,55,65,75$ \\
$\mathrm{i}_{\text {tkk_ } 2011}$ & 35 & 45 \\
$\mathrm{i}_{\mathrm{tkk} \_} 2011$ & 55 & 65,75 \\
\hline
\end{tabular}

ISF - indirect site factor, $\mathrm{i}_{\mathrm{h}-}$ height increment (measured from 2008 to 2011), $i_{\text {tkk }}$ - increment of diameter at root collar (measured in 2011)

\section{Discussion}

No significant growth response of fir to light was found in the range of relative radiation from 5 to $55 \%$ and canopy openness of $30 \%$ on the research plots established from 2007 to 2009. The height increment of trees in this radiation range was $10 \mathrm{~cm}$. Significant differences were observed only in 2011, so we assume that differences in the increment of fir in varying light conditions, become evident after a longer period of time (Svoboda 1953; Stancioiu and O'Hara 2006b).

Our results confirm the well-known fact that fir regeneration tolerates high degree of shading (Svoboda et al. 2005; Stancioiu and O'Hara 2006c). This trait of fir reduces potential competition with spruce regeneration and forest ground vegetation (Grassi and Bagnaresi 2001; Hunziker and Brang 2005; Stancioiu and O'Hara 2006b). Stancioiu and O'Hara (2006b) attributed a role not only to PACL, but also to the size of the basal area. They state that fir cannot compete with spruce when basal area values are smaller than $25-15 \mathrm{~m}^{2} /$ ha and PACL greater than $80-90 \%$, while it is able to grow as fast as spruce in conditions of basal area values of $15-35 \mathrm{~m}^{2} / \mathrm{ha}$ and PACL values of $35-70 \%$. This is confirmed by our results, which suggest optimal conditions of maximum canopy openness $30 \%$, stand basal area $30-43 \mathrm{~m}^{2} /$ ha, maximum DSF and ISF values $45 \%$ and $55 \%$, respectively, for the establishment and initial growth of fir. Robakowski et al. (2003) showed that $18 \%$ of radiation represents the most suitable light conditions for the growth of fir seedlings.

Nagel et al. (2006) stated that fir regenerates and grows under the canopy and does not need gaps for regeneration as the similarly shade tolerant beech. It is capable of growing in the shading of a mature stand and "waiting for an opportunity" for the very long period of several decades (Zatloukal 2001). This opinion is in agreement with the results of our work, which recommend a uniform opening of the stand without formation of larger gaps to ensure a higher proportion of ISF over DSF (see Fig. 5). This ratio positively affected the height increment of seedlings.

Regeneration carried out at openness values of about $16 \%$ (see plots 2 and 3 ) can grow more than 10 $\mathrm{cm}$ per year already three years after planting in the conditions of NPČš. This fact is confirmed by Zatloukal (2001), who states that fir can achieve annual height increments of 10 to $15 \mathrm{~cm}$ in a nearly closed stand. Moreover, fir produces the best size ratio between the crown and the root system in shaded conditions.

From another point of view, intense cutting is not conform with the environmental requirements of fir, because it leads to intensive disturbance of the microclimate (Dai 1996; Nicotra et al. 1999), which is not tolerated by this species (Kantor 2001). The longeval 
fir needles are not capable of quick adaptations to new environmental conditions (Svoboda 1953). Planting under a shelterwood is therefore recommended as a suitable method of restoration, which may be, under certain conditions, substituted by regeneration by strip. This suggestion is supported by the study of Kantor (2001), which recommended regenerating fir by regeneration under a shelterwood or regeneration by strips of about $40 \times 20 \mathrm{~m}$. According to this author, regeneration by strip is, providing conformance with the environmental requirements of fir, operationally more suitable, because is it simpler and easier. Regenerating by strip, it is necessary to plan the exposure and shape of the felling in such a way that the seedlings are shaded for the most of the day (Kantor 2001; Holst et al. 2005; Hu et al. 2010). In addition, Kantor (2001), recommended ensuring a long regeneration period with differential spatial arrangement in the newly established stands. In Slovakia, small area shelterwood felling with longer regeneration period of 20 to 30 years proved as the most suitable regeneration approach (Saniga 2001). Muscolo et al. (2010) recommended even smaller gaps of $185 \mathrm{~m}^{2}$ for the natural regeneration of fir.

The results of our research showed that the establishment of fir seedlings was faster on acidic soil (4K, 5K; Plíva 1987), but the height increment stagnated in the subsequent years and the growth dynamics appeared to be more balanced on luvisol (ilimeritic soil $-4 \mathrm{I}$ and $5 \mathrm{I}$ ), which is deeper and has higher content of clay and nutrients in comparison with the acidic soil. These findings confirm the environmental requirements of fir, which prospers better in deep soil (Svoboda and Pokorný 1953, Míchal and Petříček 1999). Šindeláŕ and Frýdl (2004), even claim that there is no adequate compensation for fir on heavy gley soils in the central and higher altitudes of the Czech Republic. Kubačka (2001) also stated that heavy loam to clay soils are the most suitable soils for fir.

A major limiting factor in many places and a specific research topic is the browsing of game, which causes considerable mortality in fir plantations and regeneration (eg Zatloukal 2001; Šindelář and Frýdl 2004; Úradníček and Maděra 2005, Diaci et al. 2010). When the regeneration areas are unfenced, the growth of the seedlings stagnates, which has to be compensated for by at least two seasons (Hasler et al. 2008). There is also danger of the total loss of the regeneration (Svoboda 1953; Úradníček and Maděra 2005). These conclusions are confirmed by our measurements on the unfenced plot 1 , which considerably differed from the results obtained on the other plots. Unprotected fir is damaged even in areas where beech, which is also preferred by game, regenerates without fencing. This experience from NPČ S is in accordance with reports from Šumava National Park (Zatloukal 2001).

\section{Conclusion}

In this study, growth of fir plants in relation to different light and soil conditions as well as game impact was investigated in selected mature spruce stands in the National Park České Švýcarsko. Browsing of game was determined as the main limiting factor for the artificial fir regeneration. It significantly affected the fir height increment on the unfenced research plot.

Assessing the impact of soil conditions on the increment of fir in the first years after planting, differences in height increment were demonstrated between acidic and ilimeritic soils (luvisol). The increments seem to be more dynamically balanced on the luvisol in the first years after planting. It is therefore appropriate to plant fir preferentially on sites with ilimeritic soils in the area of NPČš.

Higher values of direct and diffuse radiation than $55 \%$ (which corresponds to canopy openness of up to $30 \%$, see fig. 6 and 7) impact the increment of fir rather negatively in the first years after planting. In contrast, the diameter increment of fir continuously increased with increasing light intensity. Both the height and diameter increment of the fir seedlings positively responded to a higher proportion of diffuse radiation as expressed by the DSF:ISF ratio. This higher proportion of diffuse light can be achieved by a rather uniform opening of the stand without formation of larger gaps. A reduction of the stand basal area to $30-43 \mathrm{~m}^{2} /$ ha seems therefore optimal for initial stage of fir regeneration. Regeneration under a shelterwood is therefore suggested as the appropriate reproduction method.

\section{Acknowledgements}

This study was supported by Internal Grant Agency 2010 of Faculty of Forestry and Wood Science (grant No. 201043120050), Internal Grant Agency 2011 of Faculty of Forestry and Wood Science (grant No. 4312013123129) and The National Agency for Agriculture Research (grant No. QI102A085).

\section{References}

Abraham V. 2006. Přirozená vegetace a její změny $\mathrm{v}$ důsledku kolonizace a lesnického hospodaření v Českém Švýcarsku. Thesis. Univerzita Karlova v Praze, Praha, 69 p.

Aussenac G. 2000. Interactions between forest stands and microclimate: Ecophysiological aspects and consequences for silviculture. Annals of Forest Science 57: 287-301.

Budín F. 1947. Časové spisky lesnické. Matice lesnická, Písek, 108 p.

Canham C.D., Denslow J.S., Platt W.J., Runkle J.R., Spies T.A., White P.W. 1990. Light regimes beneath closed canopies and tree-fall gaps in tem- 
perate and tropical forests. Canadian Journal of Forest Research 20: 620-631.

Dai X. 1996. Influence of light conditions in canopy gaps on forest regeneration: a new gap light index and its application in a boreal forest in east-central Sweden. Forest Ecology and Management 84: 187-197.

Diaci J. 2002. Regeneration dynamics in a Norway spruce plantation on a silver fir beech forest site in the Slovenian Alps. Forest Ecology and Management. 161: 27-38.

Diaci J., Rozenbergar D., Boncina A. 2010. Stand dynamics of Dinaric old-growth forest in Slovenia: are indirect human influences relevant? Plant Biosystems 144: 194-201.

Dobrovolný L. 2010. Pronikání buku (Fagus sylvatica L.) do smrkové monokultury $z$ jednotlivě vtroušených mateřských porostů - iniciální fáze. Dissertation. Mendelova univerzita v Brně, Brno, 243 p.

Elling W., Dittmar Ch., Pfaffelmoser K., Rötzer T. 2009: Dendroecological assessment of the complex causes of decline and recovery of the growth of silver fir (Abies alba Mill.) in Southern Germany. Forest Ecology and Management 257: 1175-1187.

Grassi G., Bagnaresi U. 2001. Foliar morphological and physiological plasticity in Picea abies and Abies alba saplings along a natural light gradient. Tree Physiology 21: 959-967.

Härtel H., Šteflová D., Drozd J. 2007. Plán péče Národního parku České Švýcarsko. Správa Národního parku České Švýcarsko, Krásná Lípa, 207 p.

Hasler H., Senn J., Edwards P.J. 2008. Light-dependent growth responses of young Abies alba to simulated ungulate browsing. Functional Ecology 22: 48-57.

Holst T., Rost J., Mayer H. 2005. Net radiation balance for two forested slopes on opposite sides of a valley. International Journal of Biometeorology 49: 275-284.

Hu L., Yan B., Wu X., Li J. 2010. Calculation method for sunshine duration in canopy gaps and its application in analyzing gap light regimes. Forest Ecology and Management 259: 350-359.

Hunziker U., Brang P. 2005, Microsite patterns of conifer seedling establishment and growth in a mixed stand in the southern Alps. Forest Ecology and Management 210: 67-79.

Kantor P. 2001. Obnova jedle bělokoré. In: Pěstování a umělá obnova jedle bělokoré: Sborník referátů z celostátního semináře. Kotrla K., Kyslík P. (eds.). AVE Centrum, Chudobín u Litovle, pp. 5-13.

Kazda M., Pichler M. 1998. Priority assessment for conversion of Norway spruce forests through introduction of broadleaf species. Forest Ecology and Management 102: 245-258.
Kubačka J. 2001. Historie a současnost JD bělokor u Ol LČR Krnov. In: Pěstování a umělá obnova jedle bělokoré: Sborník referátů z celostátního semináře. Kotrla K., Kyslík P. (eds.). AVE Centrum, Chudobín u Litovle, pp. 70-76.

Kuiters A.T., Slim P.A. 2002. Regeneration of mixed deciduous forest in a Dutch forest-heathland,following a reduction of ungulate densities. Biological Conservation 105: 65-74.

Kuneš P., Pokorný P., Abrahám V. 2005. Rekonstrukce přrirozené vegetace pískovcových skal NP České Švýcarsko a přilehlého pískovcového území formou pylových analýz. Karlova univerzita v Praze, Praha, 20 p.

Lesprojekt 2007. Forest management plan of $\mathrm{Na}-$ tional park České Švýcarsko - text part. Lesprojekt, Hradec Králové, 228 p.

Málek J. 1983. Problematika jedle bělokoré a jejího odumírání. Academia, Praha, 108 p.

Maxime C., Hendrik D. 2011. Effects of climate on diameter growth of co-occurring Fagus sylvatica and Abies alba along an altitudinal gradient. 25: 265-276.

Míchal I., Petříček V. 1999. Péče o chráněná území. II. Lesní společenstva. AOPK ČR. Praha, 713 p.

Mosandl R., Kleinert A. 1998. Development of oaks (Quercus petraea (Matt.) Liebl.) emerged from bird-dispersed seeds under old-growth pine (Pinus silvestris L.) stands. Forest Ecology and Management 106: 35-44.

Muscolo A., Sidari M., Mercurio R. 2007. Variations in soil chemical properties and microbial biomass in artificial gaps in silver fir stands. 126: 59-65.

Muscolo A., Sidari M., Bagnato S., Mallamaci C., Mercurio R. 2010. Gap size effects on above- and below-ground processes in a silver fir stand. 129: 355-365.

Musil I. 2003. Jehličnaté dřeviny. Česká zemìdilská univerzita, Praha, $177 \mathrm{p}$.

MZe 2007. Zpráva o stavu zemědělství ČR za rok 2007. Ministry of Agriculture, Praha, 222 p.

MZe 2010. Zpráva o stavu zemědělství ČR za rok 2010. Ministry of Agriculture, Praha, 224 p.

Nagel T.A., Svoboda M., Diaci J. 2006. Regeneration patterns after intermediate wind disturbance in an old-growth Fagus-Abies forest in southeastern Slovenia. Forest Ecology and Management 226: 268-278.

Nicotra A.B., Chazdon R.L., Iriarte S.V.B. 1999. Spatial heterogeneity of light and woody seedling regeneration in tropical wet forests. Ecology 80: 1908-1926.

Pèlachs A., Pérez-Obiol R., Ninyerola M., Nadal J. 2009. Landscape dynamics of Abies and Fagus in the southern Pyrenees during the last 2200 years as a result of anthropogenic impacts. Review of Palaeobotany and Palynology 156: 337-349. 
Phillips D.L., Shure D.J. 1990. Patch-size effects on early succession in southern Appalachian forests. Ecology 71: 204-212.

Pinto P.E., Gégout J., Hervé J., Dhôte J. 2008. Respective importance of ecological conditions and stand composition on Abies alba Mill. dominant height growth. Forest Ecology and Management 255: 619-629.

Plíva K. 1987. Typologický klasifikační systém ÚHUL. ÚHUL, Brandýs nad Labem, $52 \mathrm{p}$.

Robakowski P., Montpied P., Dreyer E. 2003. Plasticity of morphological and physiological traits in response to different levels of irradiance in seedlings of silver fir (Abies alba Mill). Tree Structure and Function 17: 431-441.

Saniga M. 2001. Stav a význam jedle bielej (Abies alba Mill.) v lesoch Slovenska. In: Pěstování a umělá obnova jedle bělokoré: Sborník referátů z celostátního semináře. Kotrla K., Kyslík P. (eds.). AVE Centrum, Chudobín u Litovle, pp. 33-36.

Stancioiu P.T., O'Hara K.L. 2006a. Morphological plasticity of regeneration subject to different levels of canopy cover in mixed-species, multiaged forests of the Romanian Carpathians. 20: 196-209.

Stancioiu P. T., O’Hara K. L. 2006b. Regeneration growth in different light environments of mixed species, multiaged, mountainous forests of Romania. 125: 151-162.

Stancioiu P.T., O'Hara K.L. 2006c. Leaf area and growth efficiency of regeneration in mixed spe- cies, multiaged forests of the Romanian Carpathians. 222: 55-66.

Svoboda P. 1953. Lesní dřeviny a jejich porosty, část I. SZN, Praha, 411 p.

Svoboda P., Pokorný J. 1953. Lesní dřeviny a jejich porosty. Praha Státní pedagogické nakladatelství, Praha, $112 \mathrm{p}$.

Svoboda M., Nagel T., Hahn K., Nielsen A.B., Roženbergar D., Diaci J. 2005. Co nevíme o ekologii jedle bělokoré. In: Jedle bělokorá - 2005. European silver fir - 2005: sborník z referátů: Srní, 31.10-1.11.2005. Neuhöferová P. (eds.). Lesnická práce, Kostelec nad Černými lesy, pp. 9-11.

Šindelář J., Frýdl J. 2004. Některé výsledky výzkumu jedle bělokoré, závěry pro lesnickou praxi. VÚLHM, Jíloviště-Strnady, 6 p.

Úradnícěk L., Maděra P. 2005. Jedle - Královna evropských lesů. In: Jedle bělokorá - 2005. European silver fir - 2005: sborník z referátů: Srní, 31.10-1.11.2005. Neuhöferová P. (eds.). Lesnická práce, Kostelec nad Černými lesy, pp. 69-74.

Zatloukal V. 2001. Možnosti pěstování jedle s ohledem na její ekologické nároky a prrirozené rozšíření. In: Pěstování a umělá obnova jedle bělokoré: Sborník referátů $\mathrm{z}$ celostátního semináře. Kotrla K., Kyslík P. (eds.). AVE Centrum, Chudobín u Litovle, 18-27 p.

Zerbe S. 2002. Restoration of natural broad - leaved woodland in Central Europe on sites with coniferous forest plantations. Forest Ecology and Management 167: 27-42. 